Jurnal Keperawatan Padjadjaran

ISSN 2338-5324 (print)

ISSN 2442-7276 (online)

Online di http://jkp.fkep.unpad.ac.id

DOI : $10.24198 / \mathrm{jkp}$

\title{
Demonstration and Audio-Visual Methods for Improving Knowledge, Attitude and Skills of Breast Care among Pregnant Women
}

\author{
Wirda Hayati ${ }^{1}$, Dewi Marianthi ${ }^{1}$, Nurhayati Nurhayati ${ }^{1}$, Tantut Susanto ${ }^{2}$ \\ ${ }^{1}$ Poltekkes Kemenkes Aceh, Banda Aceh, Indonesia \\ ${ }^{2}$ Faculty of Nursing, Universitas Jember, Jember, Indonesia \\ Corresponding email:wirda_hayati@yahoo.com
}

Submitted: 13-02-2020 Accepted: 08-04-2020 Published: 12-04-2020

\begin{abstract}
One of the physical changes during pregnancy is their breasts that usually get larger and heavier, the areola mammae becomes darker and the nipples get bigger. These conditions cause the breasts need to be treated in preparation for exclusive breastfeeding. However, in reality, there are many pregnant women who have not done much breast care due to their ignorance of its importance and lack of information. The aimed this study was to identify the effective of audio-visual and demonstration method for improving knowledge, attitude, and skills of breast care among pregnant women in Aceh. This study was used a pre-test post-test design with a control group (37 of pregnant women) and intervention group (36 of pregnant women). The intervention group was given health education about breast care using demonstration method, while the control group was given by watching videos. The instruments used in this study was a questionnaire about breast care and checklist to assess breast care skill. The instruments was developed based on the existing theory. Data was analyzed using t-independent test $(\mathrm{p}<0.05)$. There were significantly difference of knowledge $(72.83+8.48$ vs. $45.43+12.06)$, attitudes $(58.76+6.20$ vs. $46.83+4.58)$, and skill $(73.74+7.98$ vs. $56.17+10.62)$ of breast care between intervention and control group among pregnants women $(\mathrm{P}<0.001)$. Furthermore, the scores of knowledge, attitudes, and skills of breast care among pregnant women using demonstration (intervention groups) method were more higher compared pregnant women using audio-visual method (control groups). Health education using demonstration method is more effective for improving knowledge, attitudes, and skills of breast care among pregnant women than audio visual method. Therefore, demonstrations and re-demonstration using guideline should be implement for women with guidance during pregnant.
\end{abstract}

Keywords: Audio-visual, breast, care, demonstration, education, health, videos, watching. 
Wirda Hayati: Demonstration and Audio-Visual Methods for Improving Knowledge, Attitude and Skills

\section{Introduction}

Pregnancy causes a pregnant woman to experience hormonal changes in her body, causing various physiological and psychological changes. One of the changes occurs in the breast. Changes in the breast have started since the fourth week of pregnancy. These changes occur due to the increased blood flow to the breast area. Some breast changes that occur are tingling, pain, or become more sensitive, especially in the nipple area. The nipples also become bigger, more upright and the areola becomes darker. In addition, the formation of glands and the development of milk ducts for milk production. This makes the breast size also becomes larger. These transformations develop together with the increase of the gestational age, as in the third trimester the breasts are getting bigger and sometimes there is even a fluid discharge (Fauziah \& Sutejo, 2017; Deswani dkk., 2019).

Breast changes during pregnancy can certainly cause discomfort and sometimes even pain in the breast. Therefore, it is necessary to do breast care. Breast care during pregnancy is very important to increase milk production which will be the sole source of nutrients for babies. Breast care should be done when the gestational age has entered the second trimester, or when the gestational age reaches 5 to 6 months (Fauziah \& Sutejo, 2017; Hamilton, 2010).

Breast care during pregnancy is an important thing to do as the preparation for breastfeeding after the baby is born. Breasts need to be prepared since pregnancy so that they can provide and deliver the milk needed by the newborns baby. Breast care also highly contributes to the success of early and exclusive breastfeeding (Deswani dkk., 2019; Hamilton, 2010).

Breast care during pregnancy can provide many benefits. For instance, the breast hygiene will be maintained, especially in the nipple and areola areas which are getting darker during pregnancy, also flexing and strengthening the nipples so that it will be easier for babies in breastfeeding. Breast care also stimulates the mammary glands so that the milk production is well and smooth. Additionally, it can detect early breast abnormalities and also prepare the mother mentally for breastfeeding (Adam et al., 2016; Bobak, 2012).

A research conducted by Adam et al. (2016) showed a significant relationship between breast care during pregnancy and exclusive breastfeeding. Out of 44 women who paid attention to breast care during pregnancy, 30 of them gave exclusive breastfeeding. The same study was done by Al Hadar and Umaternate (2016), and found that there was a significant relationship between breast care during pregnancy and exclusive breastfeeding.

In fact, currently, there are many pregnant women who do not pay attention to breast care during pregnancy. This is caused by their ignorance on how to take care of their breasts. The results or risks that can arise from not doing breast care are shrunken nipples, low milk production or no produced milk, breast infection and various other disorders (Jamaan, 2018). To prevent these, it is necessary to do health education regarding breast care for pregnant women.

Health education can be form a good behaviour, that was caused health education is one of way to gain the knowledge, attitude and skill. The research result by Purnamasari, et. al (2011) about health education by sms center pregnancy to knowledge abaout maternal and child health in Bandung, shown a significant difference $(\mathrm{p}=0.000)$ between the knowledge before and after the pregnancy center of SMS. The other, if the people had a knowledge, that make them to compliance to do something. The study by Naim (2017) about effect of family-based education towards pregnant women intension for nutrision optimalize at 1000 first day of life, shown that there was a significant effect between the family-based education towards pregnant women intention to optimize the nutrition of 1000 first days of life $(p=0.00)$. The results of studies shown that the health education can make the positive behaviour.

Various methods of health education about breast care during pregnancy can be done. Edgar Dale said that providing direct experience during learning is a real practice and making it easier to understand what is being taught. Likewise, if health education about breast care is carried out by demonstration for pregnant women, they 
Wirda Hayati: Demonstration and Audio-Visual Methods for Improving Knowledge, Attitude and Skills

will understand easily and will be able to do it directly. Also, if health education is given using videos, the information about breast care will also be accepted easier and is more effective than using text and images. The reason is that with the videos, people will use both their sense of sight and sense of hearing in receiving the information (Nugraha, 2019).

Research by Wulandari (2017) about the relationship between the level of knowledge of pregnant women and their attitude towards breast care revealed that as many as $47 \%$ of respondents had a proficient knowledge and $53 \%$ of respondents were lack of knowledge. Regarding the mother's attitude towards breast care, it was found that 58\% had negative attitude and $42 \%$ had positive attitude. Statistical test results also stated that there was a relationship between knowledge and the mothers' attitude in doing breast care during pregnancy.

The discussions that were previously mentioned clearly explain the importance of breast care that must be done by pregnant women to prepare for the breastfeeding process. However, in fact, there are many pregnant women who have not done so because of their ignorance. To overcome this problem, various methods of health education can be done to increase the knowledge, skills and attitudes of mothers regarding the breast care, including the methods of demonstration and watching videos on how to do breast care. In earlier study researcher didn't found the specific study about demonstration and watching video methods to gain the knowledge, skills and attitudes of pregnant women, but the study more explained about the breast feeding and the other health education for health during pregnancy. So, this study wants to figure out which health education method is the most effective between demonstration or watching video methods to forming behaviour about breast care in pregnant women.

This research is expected to make a positive contribution to pregnant women in the form of knowledge development about breast care so that they can have a healthy pregnancy. In addition, it is also an input for health workers to design effective learning method(s) in providing health education to pregnant women about breast care. Therefore, the aimed this study want to the effective of audio-visual and demonstration method for improving knowledge, attitude, and skills of breast care among pregnant women in Aceh.

\section{Method}

This study used a pre-test post-test design with control group. The treatment group received an intervention of health education about breast care by demonstration technique. Meanwhile, health education about breast care for the control group was given through watching videos. Sampling was done by purposive sampling technique with criterions the pregnant women in second or third semester of pregnant at public health center, with a total sample of 73 participants. The sample of the intervention group was 37 participants, and the control group was 36 participants.

The study was conducted in the working area of the public health centre in Aceh. The duration of the research process was 3 months. Pre data collection was done for one day in each group while post data collection was done one week after the health education process had been carried out.

The study was conducted by distributing samples into two groups randomly using paper rolls. The respondents who picked up a paper roll labeled with letter $P$, they would be included in the treatment group. If their paper roll was labeled with letter K, they should be in the control group. After the distribution of respondents, the study started with the control group by providing them with health education about breast care through watching videos.

Previously, the writer measured the respondents' knowledge, attitudes and skills, then measured them again a week after the health education. In the second week, the treatment was carried out for the intervention group in the form of health education about breast care using demonstration method. The writer also measured the respondents' knowledge, attitudes and skills before treatment and measured it again one week after the treatment. In collecting the data, the writer used a questionnaire about knowledge, attitudes and skills in pregnant women. The 
Wirda Hayati: Demonstration and Audio-Visual Methods for Improving Knowledge, Attitude and Skills

data then being processed and analyzed using the univariate analysis to calculate the frequency distribution and using bivariate analysis for value differences. The pre-and post-test values were tested using paired t test and the differences between the intervention

and control groups were checked by using unpaired $t$ test.

\section{Results}

Table 1 Distribution Frequency of Demographic Data of Participants $(N=73)$

Demographic Data $\quad$ Frequency (f)

Percentage

(\%)

\begin{tabular}{llll}
\hline Age (years) & Less than 25 & 26 & 35.6 \\
\multirow{2}{*}{ Qualification } & $26-35$ & 47 & 64.4 \\
& High school & 45 & 61.6 \\
Employment & University & 28 & 38.4 \\
& Employed & 30 & 41.1 \\
Gestational Age & Unemployed & 43 & 58.9 \\
\multirow{2}{*}{ Number of Pregnancy } & Trimestes II & 33 & 45.2 \\
& Trimester III & 40 & 54.8 \\
& Primi Gravida & 53 & 72.6 \\
\hline
\end{tabular}

Table 2 Score Differences between Pre-Test and Post-Test of Knowledge, Attitude and Skill about Breast Care in Intervention Group

\begin{tabular}{llccc}
\hline & Variable & \multicolumn{2}{c}{ Video Experiment Group } & \multirow{2}{*}{ p-Value } \\
\cline { 3 - 4 } & & Pre-Test & Post-Test & \\
\hline Knowledge & Mean + SD & $42.7+11.2$ & $72.9+9.2$ & 0.001 \\
& Range & $20-65$ & $55-85$ & \\
\multirow{2}{*}{ Attitude } & Mean + SD & $47.6+2.5$ & $58.8+6.2$ & 0.001 \\
& Range & $44-55$ & $48-75$ & \\
Skill & Mean + SD & $46.9+7.7$ & $73.7+7.9$ & 0.001 \\
& Range & $33-60$ & $60-86$ & \\
\hline
\end{tabular}

Table 3 Score Difference between Pre-Test and Post-Test of Knowledge, Attitude and Skill About Breast Care in Control Group

\begin{tabular}{llccc}
\hline & Variable & \multicolumn{2}{c}{ Video Experiment Group } & \multirow{2}{*}{ p-Value } \\
\cline { 3 - 4 } & & Pre-Test & Post-Test & \\
\hline Knowledge & Mean + SD & $59.3+17.8$ & $53.4+13.7$ & 0.820 \\
& Range & $25-80$ & $25-80$ & \\
\multirow{2}{*}{ Attitude } & Mean + SD & $47.6+2.5$ & $47.2+2.2$ & 0.920 \\
& Range & $41-53$ & $40-53$ & \\
Skill & Mean + SD & $38.6+12.0$ & $43.02+13.6$ & 0.051 \\
& Range & $20-66$ & $13-73$ & \\
\hline
\end{tabular}

Volume 8 Issue 1 April 2020 
Wirda Hayati: Demonstration and Audio-Visual Methods for Improving Knowledge, Attitude and Skills

Table 4 Score Difference of Pre-Test and Post-Test of Knowledge, Attitude and Skill About Breast Care between Intervention Group and Control Group

\begin{tabular}{|c|c|c|c|c|c|}
\hline \multirow[t]{2}{*}{ Variable } & \multirow[t]{2}{*}{ Mean+SD } & \multirow{2}{*}{$\begin{array}{c}\text { Mean } \\
\text { Difference }\end{array}$} & \multicolumn{2}{|c|}{$95 \% \mathrm{CI}$} & \multirow[t]{2}{*}{ p-value } \\
\hline & & & Lower & Upper & \\
\hline \multicolumn{6}{|l|}{ Knowledge } \\
\hline Intervention Group & $72.83+8.48$ & -25.33 & 27.77 & 38.84 & 0.001 \\
\hline Control Group & $45.43+12.06$ & -7.98 & & & \\
\hline \multicolumn{6}{|l|}{ Attitude } \\
\hline Intervention Group & $58.76+6.20$ & 11.15 & 3.63 & 8.79 & 0.021 \\
\hline Control Group & $46.83+4.58$ & 4.94 & & & \\
\hline \multicolumn{6}{|l|}{ Skill } \\
\hline Intervention Group & $73.74+7.98$ & 26.78 & 12.19 & 24.01 & 0.001 \\
\hline Control Group & $56.17+10.62$ & 9.55 & & & \\
\hline
\end{tabular}

The results of this study include demographic data, knowledge, attitudes and skills as presented in Table 1.

Table 1 showed that the majority of the respondents were in the early adult category (26-35 years) at $64.4 \%$, the education qualification was in the high school category at $61.6 \%$, most of the mothers were unemployed at $58.9 \%$ and the most gestational ages were in the trimester III at $54.8 \%$ with the highest number of pregnancies being primigravida at $72.6 \%$.

Table 2 showed that the score difference of pre-test and post-test of all variables after health education on breast care by demonstration method with $p$ value of $<0.05$. The post-test score of all variables indicates an increase, particularly in the knowledge variable with the lowest score of 20 in pre-test to 55 in post-test, and the highest score of 65 to 85 . It is the same for the skill variable where the lowest score of 33 increases to 60 and the highest score of 60 to 86.

Table 3 showed that the score no difference of pre-test and post-test of all variables after health education on breast care by video watching method with $p$ value of $>0.05$. The mean post-test score of the knowledge variable the same between pre and post-test were 80 , and the lowest score stays at 25 . That it's same with the attitude variable. But for the skill variable mean posttest arise that pre-test, but not significantly the was 13 score differences.

Table 4 revealed that there is a difference in result of knowledge, attitude and skill between intervention group and control group ( $\mathrm{p}<0.05)$. Out of the three variables, the biggest result is in the knowledge variable with mean difference $=26.78$.

\section{Discussion}

The research result shows that there was a score difference between the pre-test and the post-test in knowledge, attitude and skill variables after health education on breast care, for both intervention group and control group. Likewise, there was a score difference in knowledge, attitude and skill between intervention group and control group, with $p$ value of $<0.05$. It is an indication that health education on breast care effectively enhances the knowledge, attitude and skill of pregnant women on breast care.

The study about the impact of perinatal education on behaviour change toward breast feeding and smoking cessation in a healthy start population by Caine et al. (2012), shown that women with advanced education were more likely to have quit smoking, as were women who were breast feeding at hospital discharge. After controlling for education, IHS clients tended to be less likely to continue to smoke during the third trimester (OR, 0.76, 95\% CI, 0.49-1.16), as were those with a first pregnancy $(\mathrm{OR}, 0.32 ; 95 \% \mathrm{CI}, 0.10,0.98)$ and no other smokers in the home (OR, $0.25 ; 95 \%$ CI, 0.08, 0.74). Breast feeding and smoking cessation are modifiable risk factors that were impacted by behavioral interventions through case management education. 
Health education during pregnancy should be effective to gain of quality of pregnancy. That due the health education can be increase of knowledge, affective and psychomotor to prepare pregnant women for childbirth and post-partum period (Herval et al., 2019). Yikar and Nazik (2019) conducted the study about effects of prenatal education on complaints during pregnancy and on quality of life shown that providing prenatal education reduces complaints and increases quality of life of pregnant women.

However, it is crucial to understand that there are multiple contexts, and pregnant women represent multiple demographic groups. The strategies of health education must be specifically designed to provide the desired outcomes for different target groups (Herval et al., 2019). A positive pregnancy experience, ante natal care guidelines and services should be designed to deliver it, and those providing ANC services should be aware of it at each encounter with pregnant women (Downe et al., 2015).

The principles of ante natal care for pregnant women to provide advice, education, reassurance, and support. That to address and treat the minor problems of pregnancy and to provide effective screening during the pregnancy. There were many studies done which found that educated women have better pregnancy outcomes compared with uneducated women and that education during the antenatal period can reduce pregnancy and delivery complications (Al Ateeq \& Al Rusaiess, 2015). Health education during pregnancy to make positive behaviour and must be designed suitable with women pregnant. In several situation transfer of information with psychomotor skill like demonstration or watching the video about health care during pregnancy are the choices.

Learning through demonstration gives a first-hand experience for the group members. In this method, the tutor would demonstrate a certain action, and then the learners were given time to re-demonstrate what they had been thought. This kind of learning process will provide deep understanding, because the learners were directly involved in the learning process. Learners will experience and be involved in the things they are learning, and the learning process happens in real situation
(Nugraha, 2019).

Demonstration method makes the learning process more certain and concrete, so the learners can easily learn the things that they are taught. Moreover, the learning process is more interesting, and the learners are encouraged to be active in correlating between the theory and practice (Nursalam \& Effendi, 2007).

Furthermore, Millis (2002) explained that to gain optimum skill, the learning process must be done by the sequences: setting the goals by doing, analyzing skills in detail and in order, demonstrate the skills, elaborate and focus on key competencies, give opportunity to learners to try to practice under monitoring and guidance, and then giving assessment towards the effort of the learners. In the health education on breast care using demonstration method, these steps were executed. The process was commenced by setting and explaining the objective of the learning and demonstrating steps for breast care. After that, the participants retry the process taught under guidance of the tutor and the tutor then assessed what had been practiced by the participants (Bouner, 2007).

The audio visual learning method by watching video is also one of the most suggested learning methods. This is because the object or the teaching materials shown on a video is more realistic and original. This condition also gives more concrete experience to learners. Video learning method requires the learners to actively use their visual and auditory senses (Bouner, 2007; Bravo et al., 2011).

Video is a media learning that can be used to deliver messages, stimulate the minds, feelings, attention and the will of learners to keep learning. Anderson (1987 in Siwi, 2012) stated that video media can develop cognitive ability because of the stimulation of moves and sensations. Video also exhibits how to react to and do something. It can also affect behaviour and emotion, so learners can be more involved in the learning. Video is suitable media learning for skills involving moves (Akhtar \& Akbar, 2011).

The research result of Bravo et al. (2011), about video as a new learning tool to boost university students' motivations showed that the use of video carried a positive effect 
Wirda Hayati: Demonstration and Audio-Visual Methods for Improving Knowledge, Attitude and Skills

towards the improvement of their learning motivations. The content and the amount of information delivered from the video need to be considered order to increase the effectiveness. From the tutors' interviews it was discovered that video gave faster explanation compared to verbal or written explanations.

Referring to the above explanation, the two learning techniques, both by demonstration or watching video had significance towards the improvement of knowledge, attitude and skill on breast care during pregnancy. This is in line with the research by Devi et al. (2019) on the results comparison of the effectiveness of learning the obstetric palpation skill by watching video and traditional demonstration among nursing students. The result revealed significant difference of the students' skill score in the pre-test and the post-test after the learning program by video watching and traditional demonstration $(\mathrm{t}=18.35, \mathrm{p}<$ 0.001 ). Although the two methods were both effective in improving the skill learnt, the traditional demonstration had higher score compared to video watching score at the post-test $(\mathrm{t}=36.40, \mathrm{p}=0.001)$. This is similar to the research by Pradan et al. (2018) on the effectiveness of learning by demonstration and watching video towards the knowledge and skills of the students of nursing in India. The result showed that both learning methods were significant in improving the score of knowledge and skill. However, the learning method by watching video was more effective than by demonstration.

\section{Conclusion}

The research results indicated that there was a crucial difference or a significant increase in the scores of knowledge, attitude and skill before and after health education on breast care during pregnancy, both by means of demonstration and video watching. Nevertheless, the scores of knowledge, attitude and skill were higher after health education on breast care by demonstration method.

The research results shown that the demonstration method better than audio visual method to learn about skill.
It is suggested to health workers to practice on doing health education which gives firsthand experience to target learners, thus the content of the health education felt real and can be practiced directly. Demonstration method is better way to teach pregnant women about breast care. Re-demonstration of breast care needs to be conducted so learners can directly practice abaout breast care which will give an excellent learning experience. A follow-up research with more homogenous samples and a larger number of respondents needs to be conducted.

\section{References}

Adam, K.S., Korompis, M.D., \& Alow G.W.H. (2016). Perawatan payudara pada masa kehamilan dan pemberian ASI ekslusive. (Breast care during pregnancy and exclusive breastfeeding).

Akhtar, A., \& Akbar, R.A. (2011). Use of media for effective instruction its importance: Some consideration. Journal of Elementary Education. Publication of Dept. of Elementary Education. IER, University of the Punjab Lahore, Pakistan. 18, (1-2), 35-40.

Al Ateeq, M.A., \& Al Rusaiess, A.A. (2015). Health education during ante natal care: The need for more. Int J Womens Health, 7, 239242. https://dx.doi.org/10.2147\%2FIJWH. S75164

Al Hadar, F., \& Umaternate, I. (2017). Pengaruh perawatan payudara pada ibu hamil terhadap peningkatan produksi ASI di Wilayah Kerja Puskesmas Kota Kecamatan Kota Ternate Tengah Tahun 2016. Jurnal Riset Kesehatan, 6(1), 5-12. http://dx.doi. org/10.31983/jrk.v6i1.2839

Bobak, L.J. (2012). Buku ajar keperawatan maternitas (Alih Bahasa). (Maternity nursing textbook (Translated)). EGC.

Bourner, T. (2007). Teaching methods for learning outcomes. Education and Training Journal, 39(9), 344-388. https://doi. org/10.1108/00400919710192377 
Wirda Hayati: Demonstration and Audio-Visual Methods for Improving Knowledge, Attitude and Skills

Bravo, E., Garcia, B. A., Simo, P., Enache, M., \& Fernandez, V. (2011). Video as new teaching tool to increase student motivation. http:// dx.doi.org/10.1109/EDUCON.2011.5773205

Caine, V.A., Smith, M., Beasley, Y., \& Brown, H. L. (2012). The impact of prenatal education on behavioral changes toward breast feeding and smoking cessation in a healthy start population. Journal of the National Medical Association, 104(5-6), 258-264. https://doi. org/10.1016/s0027-9684(15)30159-0

Deswani, Desmarnita, U., \& Mulyanti, Y. (2019). Asuhan keperawatan prenatal dengan pendekatan neurosains. (Prenatal nursing care with a neuroscience approach). Winneka Media.

Devi, B., Khandelwal, B., \& Das, M. (2019). Comparison of the effectiveness of videoassisted teaching program and traditional demonstration on nursing students learning skills of performing obstetrical palpation. Irenian Journal of Nursing and Midwifery Research, 24(2), 118-123. https://dx.doi. org/10.4103\%2Fijnmr.IJNMR 3518

Downe, S., Finlayson, K., Tunçalp, Ö., \& Metin Gülmezoglu, A. (2016). What matters to women: a systematic scoping review to identify the processes and outcomes of antenatal care provision that are important to healthy pregnant women. International Journal of Obstetrics and Gynaecology, 123(4), 529-539. https://doi. org/10.1111/1471-0528.13819

Elisabet., \& Siwi Walyani., Endang Puroastuti. (2015). Asuhan Kebidanan Masa Nifas dan Menyusui. (Postpartum and Breastfeeding Midwifery Care). Pustaka Baru Press.

Fauziah, S., \& Sutejo. (2012). Keperawatan maternitas kehamilan. (Pregnancy maternity care). Kencana Pramedia Group.

Hamilton, P.M. (2010). Basic maternity nursing. The CV Mosby Company.

Herval, Á. M., Oliveira, D., Gomes, V. E., \&
Vargas, A. (2019). Health education strategies targeting maternal and child health: A scoping review of educational methodologies. Medicine, 98(26). https://doi.org/10.1097/ MD.0000000000016174

Jamaan, T. (2018). Perawatan payudara saat hamil hingga menjelang persalinan. Retrieved Januari 14, 2019, from https:// hellos ehat.com/kehamilan/kandungan/ prenatal/perawatan-payudara-saat-hamilhingga-menjelang-melahirkan/

Millis, J.B. (2002). Enhancing learning and more throuhgt cooperative learning. Idea Paper. Retrieved January 14, 2019, from https://files.eric.ed.gov/fulltext/ED471897. pdf

Naim, M., Juniarti, R., \& Yamin, A. (2017). Pengaruh edukasi berbasis keluarga terhadap intensi ibu hamil untuk optimalisasi nutrisi paad 1000 hari pertama kehidupan. . Jurnal Keperawatan Padjadjaran, 5(2). https://doi. org/10.24198/jkp.v5i2.475

Nugraha, R.S. (2019). Teori kerucut pengalaman belajar edgar dale. (Edgar Dale's Cone Theory of Learning Experience). Retrieved January 19, 2019 http://www. tintapendidikanindonesia.com

Nursalam \& Effendi. (2008). Pendidikan dalam Keperawatan. (Education in Nursing). Salemba Medika.

Pradan, C., Sharma, K.R., \& Srinivan, M. (2018). Effectiveness of lecture cum demonstration and lecturer cum video assisted teaching methode on knowledge and skill undergraduate Nursing Student of Selected Nursing educational. International Journal of Practical Nursing, 6(3). http:// dx.doi.org/10.21088/ijpn.2347.7083.6318.1

Purnamasari, S.S, Ermiati, E., \& Solehati, T. (2011). Pengaruh metode SMS center pregnancy terhadap pengetahuan KIA dalam Buku KIA pada ibu hamil trimester III di wilayah kerja puskesmas Puter Kota Bandung. Majalah Keperawatan Unpad, 13(2).

Wagio \& Putrono. (2016). Asuhan 
Wirda Hayati: Demonstration and Audio-Visual Methods for Improving Knowledge, Attitude and Skills

keperawatan antenatal, intranatal dan bayi baru lahir. Fisiologis dan Patologis (Edisi I).. CV. Andi Offset.

Wulandari. (2017). Hubungan antara tingkat pengetahuan ibu dengan prilaku ibu dalam perawatan payudara. [Bachelor's thesis, Stikes Al'Asyiah]. Stikes Al'Asyiah Yogyakarta

Yikar, S.K., \& Nazik, E. (2019). Effects of prenatal education on complaints during pregnancy and on quality of life. Patient Education and Counselling Journal, 102(1), 119-125. https://doi.org/10.1016/j. pec.2018.08.023 